\title{
Funastrum saganii (Apocynaceae; Asclepiadoideae; Asclepiadeae; Oxypetalinae), a new species endemic to Veracruz, Mexico
}

\author{
María Guadalupe Chávez-Hernández ${ }^{1}$ (i), Lucio Lozada-Pérez (i) and Leonardo Osvaldo Alvarado-Cárdenas* (i)
}

Received: August 7, 2020

Accepted: January 12, 2021

\begin{abstract}
A new species of Funastrum is described from Veracruz, Mexico. Although Funastrum saganii sp. nov. is morphologically similar to F. elegans and F. lindenianum, there are differences in leaf and flower morphology and geographic distribution. Descriptions, illustrations and the geographic distribution of this species are provided, and its conservation status discussed. Morphological leaf analysis was performed using geometric morphometrics. This discovery highlights Mexico as center of diversity for the genus Funastrum, with 14 of its 19 species located in the country. This finding is important because it is the first new species of Funastrum to be described from Mexico in 127 years.
\end{abstract}

Keywords: Apocynaceae, endemism, Funastrum, geometric morphometrics, Oxypetalinae, Veracruz, Mexico

\section{Introduction}

Funastrum derives from the Latin funis, which means "rope" and the suffix astrum, which means "star" or "similar". The name refers to its twining stems and its flower morphology (Austin 2010). This group belongs to the Apocynaceae, Asclepiadoideae, Asclepiadeae and Oxypetalinae (Endress et al. 2014; 2018), and has been considered as monophyletic in several analysis based on morphological and molecular data (Liede 1996; Liede \& Täuber 2000; Liede \& Meve 2003; Rapini et al. 2003; Liede-Schumann et al. 2005). Funastrum is morphologically different from other groups in Oxypetalinae given the presence of a stipitate or sessile gynostegium, a gynostegial corona with five vesicular lobes, asymmetric, erect and free, and a fleshy ring attached to the corolla tube and the base of the gynostegium (Stevens 2009).

The circumscription of the genus has been controversial since its description (Fournier 1882), due to its morphological similarity with groups distributed in Europe such as Cynanchum, or Philibertia from South America (Holm 1950). Nevertheless, Funastrum is currently recognized as a taxon endemic to the Americas, with a distribution from southern United States to northern Argentina that includes between 16 and 19 species (Endress et al. 2018; Fishbein \& Gandhi 2018).

In Mexico, the taxonomic knowledge of Funastrum has been limited to regional floras (Juárez-Jaimes \& Lozada 2003; Stevens 2009), but an updated taxonomic review has not been performed. In developing a taxonomic update of Funastrum in Mexico, the review of the herbarium material showed some individuals that could not be unequivocally identified with a species familiar to the country. The specimen is similar to F. elegans and F. lindenianum. This work describes Funastrum saganii and presents illustrations, a distribution map, and leaf morphology comparisons using geometric morphometrics techniques.

\footnotetext{
1 Departamento de Biología Comparada, Laboratorio de Plantas Vasculares, Facultad de Ciencias, Universidad Nacional Autónoma de México, 04510, Ciudad de México, Mexico

* Corresponding author: leonardo.oac77@gmail.com
} 


\section{Materials and methods}

\section{Geometric morphometrics}

We compared the specimens of the potential new species with the F. elegans (Decne.) Schltr. and F. lindenianum (Decne.) Schltr. species using geometric morphometrics. This tool has some advantages compared to traditional morphometrics because geometric information of shape differences is preserved while statistical power is increased (Adams et al. 2004). To compare the morphology of the different species, we downloaded 65 photographs of the three species from IBData (MEXU 2020), with a sample size of 30 photographs for F. elegans, 24 for F. lindenianum and 11 for $F$. saganii. Due to the small number of $F$. saganii specimens, we considered each leaf as a separate unit for analysis and only those fully developed. Each image was edited in Adobe Photoshop CS6 to set the reference scale. To digitize the landmark configuration, each image was edited in MakeFan (Sheets 2016a) by placing an equidistant 10-line comb anchored at the apex and laminar base marks. TPS file was generated using TPSUtil (Rohlf 2009). The configuration consisted of 2 landmarks, 20 semilandmarks distributed in the comb and two open curves of 7 points distributed equidistantly in each one, and digitized on the TPSDig 2.12 software (Rohlf 2008) (Fig. 1A). The scale was digitized by means of the scalar factor. The Procrustes least squares overlap was performed with the CoordGen8 software (Sheets 2016b). After that, semilandmarks were slid using the procrustes sliding method with the CoordGen8 SemiLand tool, in order to correct as much possible errors in the placement of the semilandmarks.
In order to know the distribution and variation of the sample in the morphospace, a principal component analysis was performed with the PCAGen software (Sheets 2016c). To analyze if the laminar shape of the three taxonomic groups was significantly different from each other, an analysis of canonical variables with a MANOVA in the CVAGen software (Sheets 2016d), and a jackknife assignment test with 100 replicates were performed.

\section{Taxonomic treatment}

Herbarium specimens were consulted in CIIDIR, ENCB, FCME, HUAA, MEXU, QMEX, SERO, TEX, UAMIZ, US, XAL, and the online collections of ARIZ, ASU, BCMX, COLO, DES, HCIB, K, UCR, UNM, URV, USF, SLPM. The vegetative and floral organs were measured using a digital caliper. The leaf shape was described following Radford (1986). For the description of the corona, we used the classification by Liede \& Kunze (1993). The information on the distribution, habitat and phenology was extracted from the reviewed herbarium specimens' labels. The distribution map of the species was made using the information extracted from the herbarium specimens and QGIS software (QGIS 2020). We included the distribution of morphological similar species. The IUCN criteria (IUCN 2019) were used to evaluate the state of conservation of the species.

We followed Templeton's (1989) species concept to compare it with similar taxa. The concept is based on a framework of population genetics, but has some pluralistic approaches because it does not discard other cohesive factors to explain the recognition of the species. For example, the geographic distribution, development restrictions, phenotypic variability restrictions and ecological restrictions that are the expression of morphological and habitat distinctiveness.
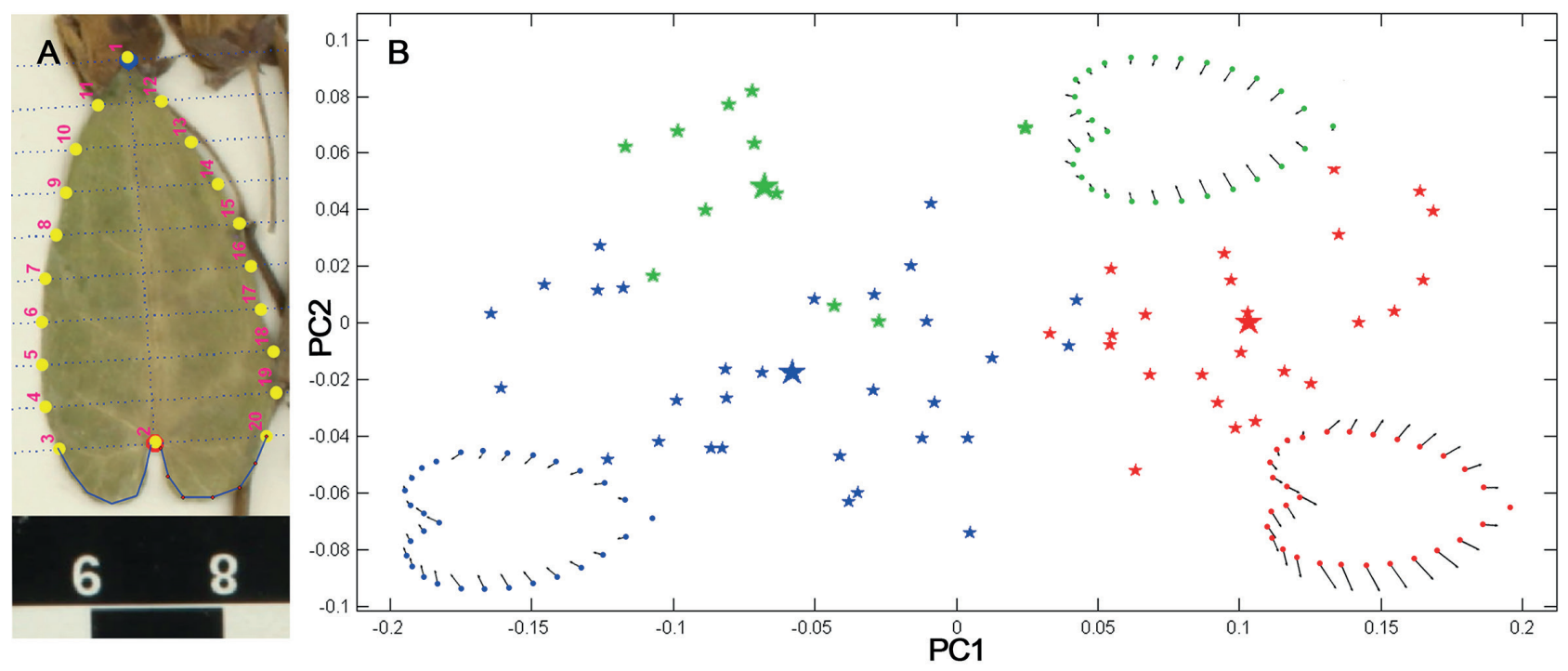

Figure 1. A. Sets of landmark and semi-landmark configuration designed to register the leaf shape in the geometric morphometrics analysis. B. PCA analysis: shape variation in leaves of Funastrum saganii (green stars), F. elegans (blue stars) and F. lindenianum (red stars) and the deformation grids corresponding to the centroid of each species (largest stars). The first two components explain the $83.58 \%$ of the variation ( $\mathrm{PC} 1=72.55 \%, \mathrm{PC} 2=11.033 \%)$. 


\section{Results}

\section{Geometric morphometrics}

The results of the analysis allowed us to visualize the leaf variation in the morphospace of the three species. In the PCA analysis (Fig. 1B), the first two components explained the $83.58 \%$ of the variation ( $P C 1=72.55 \%$, $P C 2=11.033 \%$ ) and showed that leaves of the putative species are more similar to those of F. elegans. However, the centroid of each group is separated from the others, suggesting morphological divergence between them.

From the CVA analysis (Fig. 2) two different canonical variables (p-scores: $2.61591 \times 10^{-14}$ and $1.22677 \times 10^{-7}$ ) were obtained, which supports the hypothesis that they are three different groups. The jackknife assignment test (100 replicates) showed $64.62 \%$ of correct assignments. Given the group sizes, the expected random rate of correct assignment was $35.10 \%$, which means that the separation of the groups was statistically supported. This approach, in addition to the differences observed in the reproductive structures and distribution, suggests that they are different taxa.

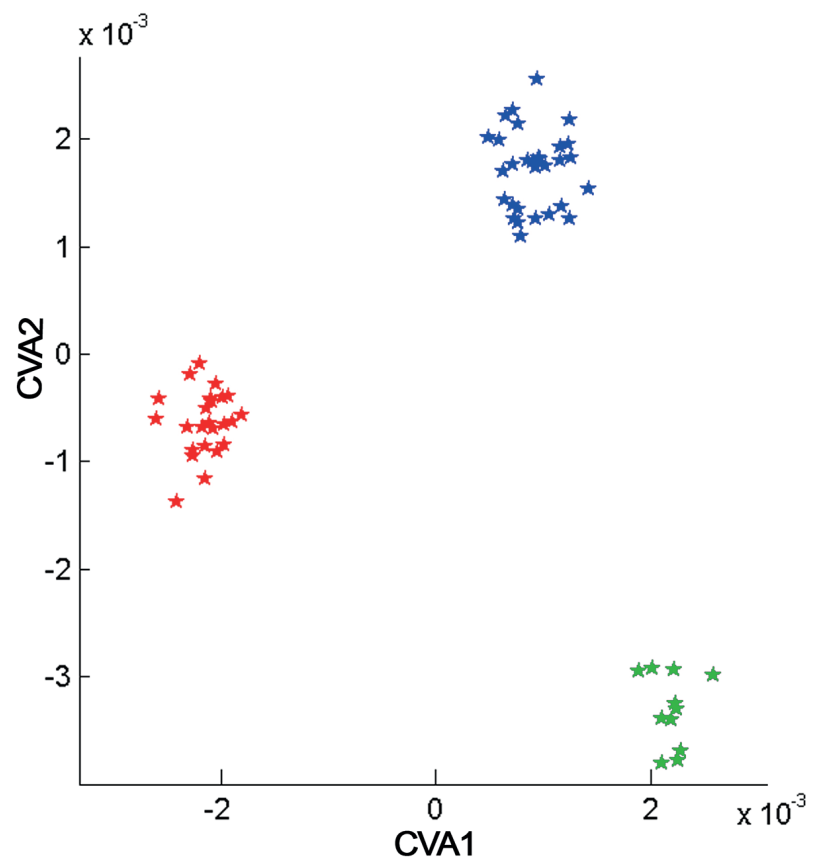

Figure 2. CVA analysis: shape variation in leaves of Funastrum saganii (green stars), F. elegans (blue stars) and F. lindenianum (red stars). Two different canonical variables ( $\mathrm{p}$-scores: $2.61591 \times 10^{-14}$ and $1.22677 \times 10^{-7}$ ) were obtained.

\section{Taxonomic treatment}

Funastrum saganii M.G. Chávez, Lozada-Pérez \& L.O. Alvarado sp. nov. (Fig. 3)
Type: MÉXICO. Veracruz: Comapa, $1 \mathrm{~km}$ al NO de El Coyol, 500 m a.s.l., $19^{\circ} 11^{\prime}$ N 96 $43^{\circ}$ 'W, 28 June 1985, M.E. Medina A. \& R. Acosta P. 189 (Holotype: XAL! Isotype: MEXU!).

Funastrum saganii is morphologically similar to F. elegans and F. lindenianum in the flower size and their ovate corolla lobes but differs from those taxa by its ovate leaves with a convergent base and by presenting more than 12 flowers per inflorescence. Also, the geographical distribution and altitude are different (Figs. 3, 4, 5).

Vine herbaceous, perennial. Latex white. Stems cylindrical uniformly pubescent, glabrescent with age, more dense at nodes, young stems with multicellular trichomes 0.25 $0.5 \mathrm{~mm}$, erect, white to translucent, without glandular trichomes. Leaves opposite, membranous; petioles 5.5 $11.4 \mathrm{~mm}$ long, pubescence more dense than on stems, multicellular trichomes $0.25-0.4 \mathrm{~mm}$, erect, white to translucent; lamina $2.6-3.8 \times 1-1.8 \mathrm{~cm}$, ovate, apex acute, frequently shortly apiculate, base lobate, frequently with converging lobes, sinus depth $4-6.8 \mathrm{~mm}$, margin entire, villous adaxially, trichomes $0.25-0.35 \mathrm{~mm}$, erect, more dense at the midvein, sparse to densely pubescent on the midveins and secondary veins abaxially, trichomes $0.35-0.5 \mathrm{~mm}$, erect, ciliated; brochidodromous venation, with $4-6$ pairs of secondary veins, colleters $3-4,0.3-0.4$ $\mathrm{mm}$ tall, on the base of the lamina. Inflorescences extraaxillary, one per node, umbelliform, with (8) 12 - 23 nodding flowers; peduncle $3.7-4.8 \mathrm{~mm}$ long, villous; bracts 2.3 - $2.5 \mathrm{~mm}$, linear-lanceolate, caducous; pedicels $1.1-1.29$ $\mathrm{cm}$ long, minutely pubescent. Calyx green, lobes 5, $2.9-$ $3.8 \times 1.5-1.7 \mathrm{~mm}$, ovate, apex acute, margins distantly ciliate, adaxial and abaxial surface vilose, trichomes 0.15 $-0.25 \mathrm{~mm}$, appressed, 1 colleter per sinus. Corolla rotate to somewhat reflexed, greenish, lobes 5, 6.4-7×3.9-5.9 $\mathrm{mm}$, ovate to widely ovate, apex rounded, margins entire, glabrous abaxially, pubescent only on the base of each lobe adaxially, trichomes ca. $0.2 \mathrm{~mm}$. Gynostegium ca. $4 \mathrm{~mm}$ long, style apex concave. Gynostegial corona of five staminal lobes fused to a basal ring formed by staminal and interstaminal parts, lobes opposite to the stamens, white, basal ring ca. $0.1 \mathrm{~mm}$ tall, lobes $2.7-3 \times 2.3-2.6 \mathrm{~mm}$, reaching the top of the anthers, ovoid-subglobose with an apex acute and a broader, truncate base. Apical anther membranes ca. $1 \mathrm{~mm}$ long, narrowly triangular. Pollinarium $1.4 \times 1.3$ $\mathrm{mm}$, corpusculum $0.44 \times 0.46 \mathrm{~mm}$, widely ovate, brown; translator arms $0.3 \mathrm{~mm}$ long; pollinia $0.8 \times 0.3 \mathrm{~mm}$, elliptic, flat. Apex of stylar head domed, not extending beyond the anther appendages. Follicles $10 \times 1.6 \mathrm{~cm}$, fusiform, glabrous. Seeds not observed. (Fig. 3).

Phenology - The specimens were collected in flower in June and fruits in October.

Distribution and habitat - Funastrum saganii is distributed in the state of Veracruz, in tropical dry forest and perturbed areas derived thereof, growing from 500 to $550 \mathrm{~m}$ a.s.l. (Fig. 5). 
Funastrum saganii (Apocynaceae; Asclepiadoideae; Asclepiadeae; Oxypetalinae), a new species endemic to Veracruz, Mexico

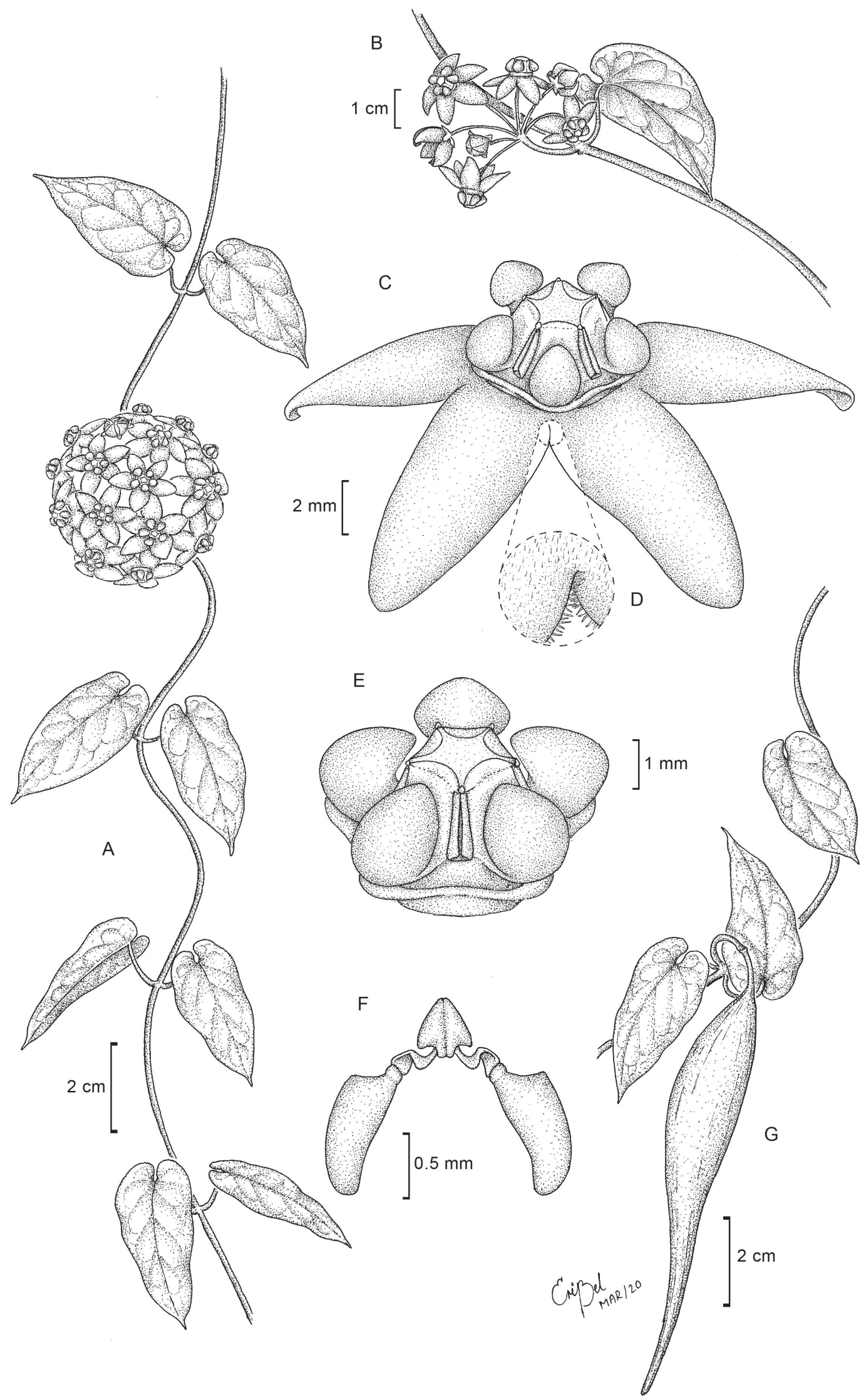

Figure 3. Funastrum saganii. A and B. Branch with leaves and an inflorescence; C. Flower; $\mathbf{D}$. Detail of the sparsely ciliate margin in the corolla lobes; E. Corona and gynostegium; F. Pollinarium; G. Branch with leaves and a fruit. 
Etymology - The name honors Carl Edward Sagan, who was an American astronomer, cosmologist, astrophysicist, astrobiologist, science disseminator, and science communicator in astronomy and other natural sciences.

Conservation status - Funastrum saganii has been collected only in two localities in Veracruz, which is one of the most disturbed areas in México, with $80 \%$ of its surface transformed and its natural vegetation already lost (Villaseñor 2015). Also, this species has not been collected in 35 years, therefore, the survival of this species could be threatened. Due to its reduced extent of occurrence (less than $100 \mathrm{~km})$, the limited area of occupancy $(8 \mathrm{~km})$ and its severely fragmented habitat (criterion B1, 2biii), we recommend the inclusion of this species in the category of critically endangered (CE) according to the red list criteria of the IUCN (2019).

Additional specimens - MÉXICO. Veracruz: Mun. Actopan, Cerro Manuel Díaz (Sierra Manuel Díaz), $550 \mathrm{~m}$ a.s.l., $19^{\circ} 33^{\prime} \mathrm{N} 96^{\circ} 27^{\prime}$ W, October 9,1985, R. Acosta P. \& J.I. Calzada 933 (XAL).
Notes - F. saganii shows a morphological similarity with F. elegans and F. lindenianum. All of them share ovate to widely ovate leaves with cordate to lobate bases (Fig. 4). The new species is distinguished by its ovate leaves with a convergent base (vs. ovates with a cordate base in F. elegans and widely ovate with a divergent base in F. lindenianum). The leaves are an important taxonomic character in the genus (Holm 1950; Goyder 2008) and the geometric morphometrics analysis supports that fact, highlighting the differences between the taxa compared (Figs. 1, 2).

On the other hand, inflorescences of $F$. saganii are characterized by presenting more than 12 flowers per inflorescence (vs. less than 12 in the other species). The flowers are greenish without stripes (vs. white to greenish with a pink stripe at the base of each lobe in F. lindenianum and reddish brown to dark purple in F. elegans). Also, F. saganii has corolla reflected and corolla lobes with margin entire or very sparsely ciliate and style apex concave (vs. corolla patent and corolla lobes densely ciliate and style apex widely bifid in F. elegans).

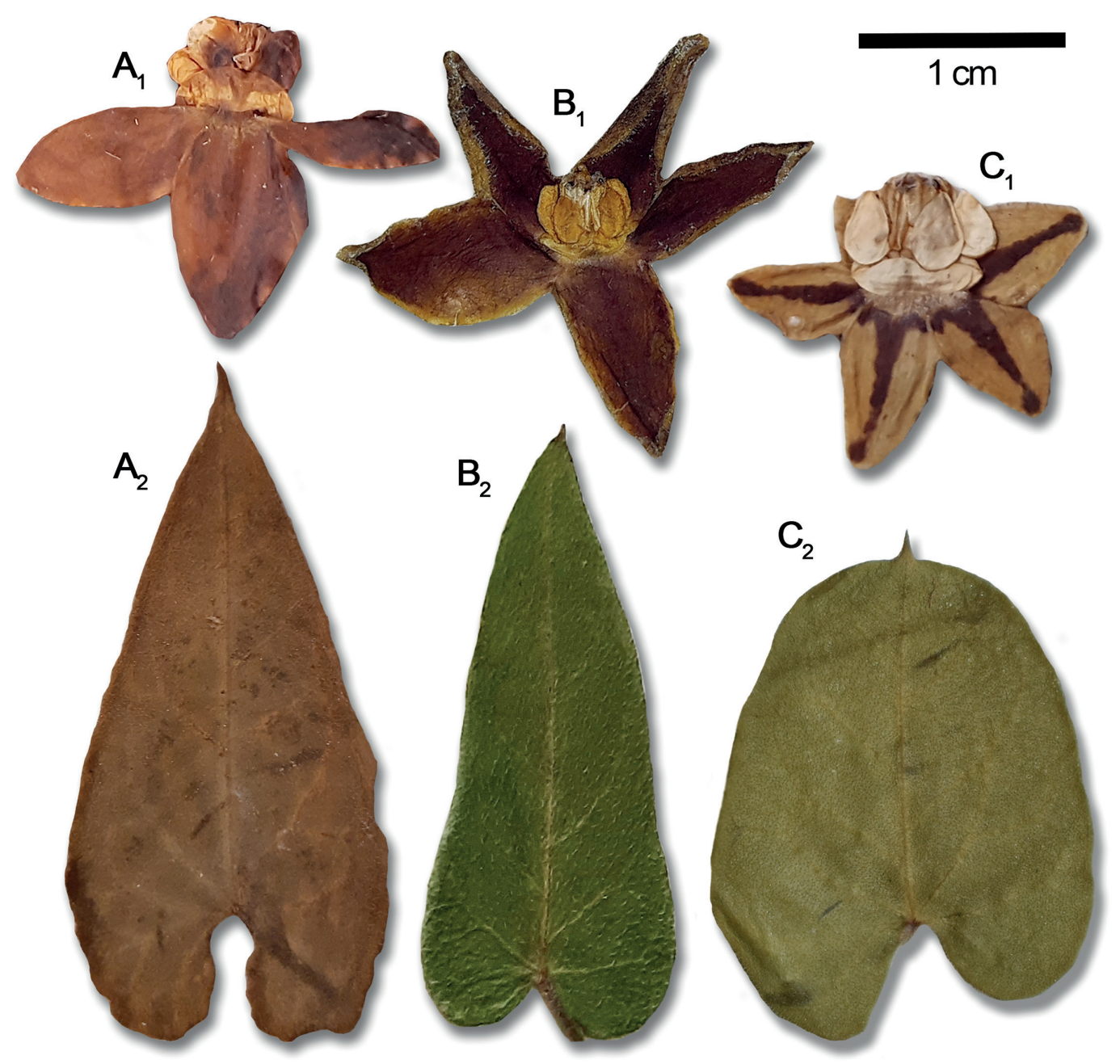

Figure 4. Morphological comparison of the flowers $\left(_{1}\right)$ and the adaxial surface of the leaves $\left({ }_{2}\right)$ of Funastrum saganii and related species, based on herbarium specimens. A. F. saganii, M.E. Medina 189 (XAL); B. F. elegans, L.I. Nevling 2157 (MEXU); F. lindenianum, G. Carnevali 4535 (ENCB). 
In addition to morphological attributes, the distribution (Fig. 4) and especially the altitude at which species grow can help differentiate groups. F. saganii is endemic to Veracruz and grows from 500 to $550 \mathrm{~m}$ a.s.l. (vs. more than $1900 \mathrm{~m}$ a.s.l. in F. elegans and less than $80 \mathrm{~m}$ a.s.l. in F. lindenianum). The new species grows near the F. elegans distribution area; however, it is separated by the Sierra Madre Oriental.

\section{Identification key for the species of Funastrum in Veracruz}

1. Peduncles longer than $7 \mathrm{~cm}$, leaves subcoriaceous with cuneate base

F. clausum

1. Peduncles shorter than $7 \mathrm{~cm}$, leaves membranous with cordate to lobate bases 2

2. Leaves with pannose vestiture abaxially, margin undulate

F. pannosum

2. Leaves with puberulent or villous vestiture abaxially, margin entire

3. Corolla patent, reddish brown to dark purple, ciliate margin

F. elegans

3. Corolla reflexed, white to greenish, glabrous or sparsely ciliate margin

4. Peduncles 1.9 to $7 \mathrm{~cm}$ long, corolla lobes with rounded apex and revolute margin

F. bilobum

4. Peduncles less than $1.4 \mathrm{~cm}$ long, corolla lobes with acute apex and entire margin

5. Leaves widely ovate, base with divergent lobes, 8 to 12 flowers per inflorescence, corolla white to greenish with a pink stripe at the base of each lobe, growing from sea level to $80 \mathrm{~m}$ a.s.l.

F. lindenianum

5. Leaves ovate, base with convergent lobes, 12 to 23 flowers per inflorescence, corolla white to greenish without a pink stripe at the base of each lobe, growing from 500 to $550 \mathrm{~m}$ a.s.l.

F. saganii

\section{Discussion}

Funastrum saganii represents an important discovery in the knowledge of the group. Since F. refractum (Smith 1893), a new species of Funastrum (with distribution in Mexico) has not been described. Also, Mexico is highlighted as a center of diversity of the genus; of the 19 species of Funastrum (Fishbein \& Gandhi 2018), 14 are distributed in the country including Funastrum saganii (Alvarado-Cárdenas et al. 2020).

This study includes, for the first time, geometric morphometrics analysis in Funastrum, showing that it is a useful tool in the species identification. In the last years, the use of geometric morphometrics has been increasing in plant taxonomy because it has shown that landmark methods are clearly superior in explaining shape and small differences between related groups compared to traditional morphometrics (Viscosi \& Cardini 2011). For example, geometric morphometrics has been a useful tool to resolve species circumscription in the Pseudolaelia vellozicola complex (Neto et al. 2019). Also, these techniques have been used to analyze the leaf morphology of black and red American oaks (Jensen 1990; Jensen et al. 1993) and discriminate species and their hybrids (Peñaloza-Ramírez et al. 2010). In our case, this tool provided additional evidence in accordance with the floral morphology, corroborating the importance

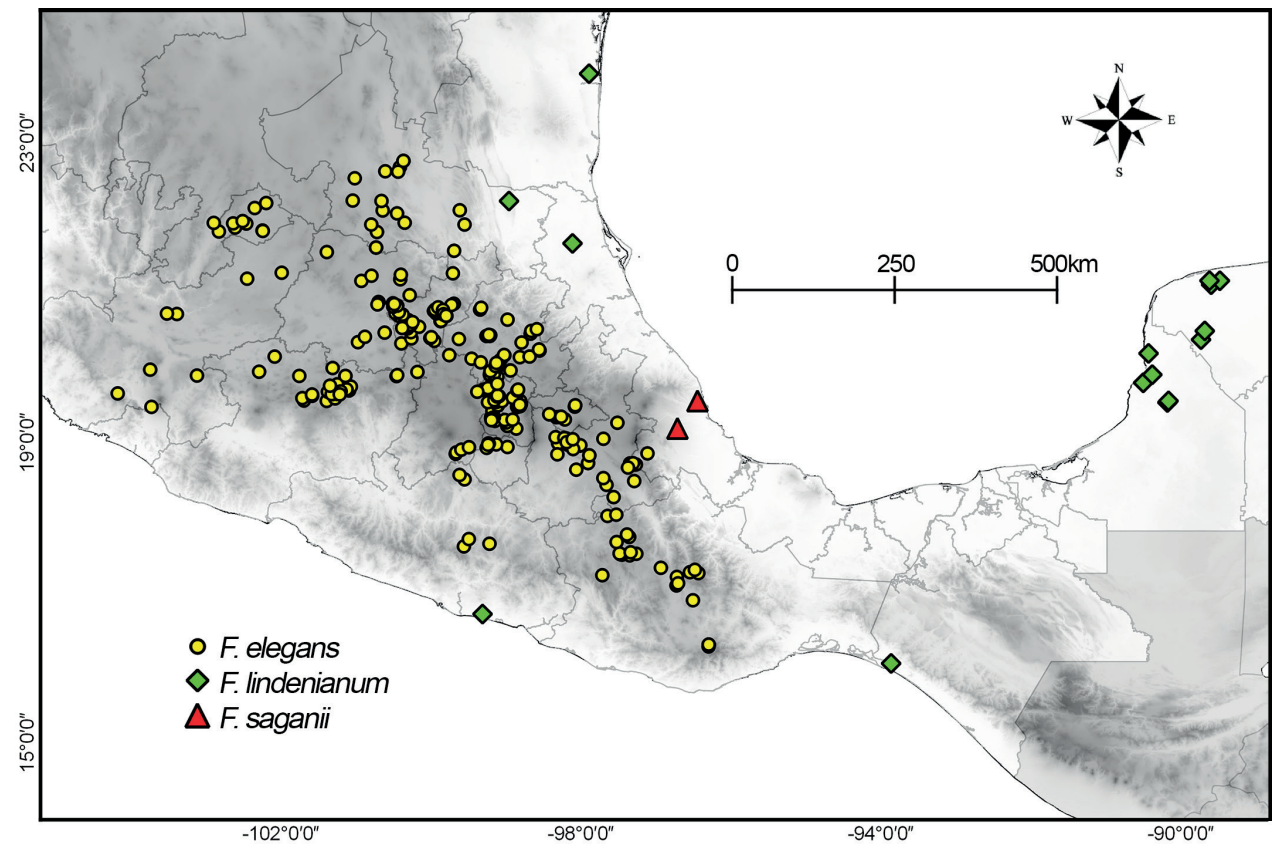

Figure 5. Known distribution of Funastrum saganii and related species. 


\section{María Guadalupe Chávez-Hernández, Lucio Lozada-Pérez and Leonardo Osvaldo Alvarado-Cárdenas}

of the leaves in the recognition of the species (Holm 1950; Goyder 2008). The application of methodologies that help us to better understand the morphology of the taxa will improve the group systematics.

\section{Acknowledgements}

We are thankful to Joel Castillo, Ixchel GonzálezRamírez, and two anonymous reviewers for their helpful suggestions. To María E. Muñiz Díaz de León for the technical support in the Taller de Biología de Plantas 1 and 2 . To the curators and technicians of the herbaria, for their assistance during the revisions of the herbarium specimens. To Ericka Belén Cortés Castro for her beautiful illustration.

\section{References}

Adams DC, Rohlf FJ, Slice DE. 2004. Geometric morphometrics: ten years of progress following the 'revolution'. Italian Journal of Zoology 71: 5-16.

Alvarado-Cárdenas LO, Lozada-Pérez L, Islas-Hernández CS, Cortez-Castro EB, Maya-Mandujano K, Chávez-Hernández MG. 2020. Apocináceas de ayer y hoy. Conocimiento histórico y reevaluación de la diversidad de Apocynaceae en México. Botanical Sciences 98: 393-416.

Austin DF. 2010. Baboquivari mountain plants: Identification, ecology, and ethnobotany. Arizona, University of Arizona Press.

Endress ME, Liede-Schumann S, Meve U. 2014. An updated classification for Apocynaceae. Phytotaxa 159: 175-194.

Endress ME, Meve U, Middleton DJ, Liede-Schumann S. 2018. Apocynaceae. In: Kadereit JW, Bittrich V. (eds.) Flowering Plants. Eudicots, The Families and Genera of Vascular Plants 1. Cham, Switzerland, Springer International Publishing AG. p. 207-411.

Fishbein M, Gandhi K. 2018. Typification of Sarcostemma heterophyllum and Nomenclatural Notes in North American Funastrum (Apocynaceae). Novon: A Journal for Botanical Nomenclature 26: 165-167.

Fournier EPN. 1882. Asclépiadées Américaines. Annales des Sciences Naturelles Botanique série 6 14: 388-389.

Goyder DJ. 2008. Funastrum rupicola (Apocynaceae: Asclepiadoideae), a new species from Bolivia. Kew Bulletin 63: 331-333.

Holm R. 1950. The American Species of Sarcostemma R. Br. (Asclepiadaceae). Annals of the Missouri Botanical Garden 37: 477-560.

IUCN - Standards and Petitions Subcommittee. 2019. Guidelines for using the IUCN red list categories and criteria. Version 14 . Prepared by the Standards and Petitions Subcommittee. http://www.iucnredlist.org/ documents/RedListGuidelines.pdf.

Jensen RJ. 1990. Detecting shape variation in oak leaf morphology: a comparison of rotational-fit methods. American Journal of Botany 77: 1279-1293.

Jensen RJ, Hokanson SC, Isebrands JG, Hancock JF. 1993. Morphometric variation in oaks of the Apostle Islands in Wisconsin: evidence of hybridization between Quercus rubra and Q. ellipsoidalis (Fagaceae). American Journal of Botany 80: 1358-1366.

Juárez-Jaimes V, Lozada L. 2003. Asclepiadaceae. Flora del Valle de Tehuacán-Cuicatlán Fascículo 37. Instituto de Biología. Universidad Nacional Autónoma de México. http://www.ibiologia.unam.mx/ BIBLIO68/fulltext/fasiculosfloras/fas37.pdf.

Liede S. 1996. Sarcostemma (Asclepiadaceae), a controversial generic circumscription reconsidered: Morphological evidence. Systematic Botany 21: 31-44.
Liede S, Kunze H. 1993. A descriptive system for corona analysis in Asclepiadaceae and Periplocaceae. Plant Systematics and Evolution 185: 275-184.

Liede S, Meve U. 2003. Dissolution of Cynanchum sect. Macbridea (Apocynaceae-Asclepiadoideae). Nordic Journal of Botany 22: 579-591.

Liede S, Täuber A. 2000. Sarcostemma R. Br. (Apocynaceae-Asclepiadoideae): a controversial generic circumscription reconsidered: evidence from trnL-F spacers. Pl. Plant Systematics and Evolution 225: 133-140.

Liede-Schumann S, Rapini A, Goyder DJ, Chase MW. 2005. Phylogenetics of the New World subtribes of Asclepiadeae (ApocynaceaeAsclepiadoideae): Metastelmatinae, Oxypetalinae, and Gonolobinae. Systematic Botany 30: 184-195.

MEXU - Herbario Nacional de México. 2020. Plantas Vasculares. En Portal de Datos Abiertos UNAM Colecciones Universitarias (en línea), México, Universidad Nacional Autónoma de México. https://datosabiertos. unam.mx/biodiversidad/. 01 Feb. 2020.

Neto LM, Berg CVD, Forzza RC. 2019. Linear and geometric morphometrics as tools to resolve species circumscription in the Pseudolaelia vellozicola complex (Orchidaceae, Laeliinae). Plant Ecology and Evolution 152: 53-67.

Peñaloza-Ramírez JM, Gonzáles-Rodríguez A, Mendoza-Cuenca L, et al. 2010. Interspecific gene flow in a multispecies oak hybrid zone in the Sierra Tarahumara of Mexico. Annals of Botany 105: 389-399.

QGIS - Development Team. 2020. QGIS Geographic Information System. Open Source Geospatial Foundation Project. http://qgis.osgeo.org. 01 Jan. 2020.

Radford AE. 1986. Fundamentals of plant systematics. New York, Harper \& Row.

Rapini A, Chase MW, Goyder DJ, Griffiths J. 2003. Asclepiadeae classification: evaluating the phylogenetic relationships of New World Asclepiadoideae (Apocynaceae). Taxon 52: 33-50.

Rohlf FJ. 2008. TpsDig, version 2.12. Stony Brook: Department of Ecology and Evolution, State University of New York at Stony Brook. http:// life.bio.sun ysb.edu/morph/. 01 Jan. 2020.

Rohlf FJ. 2009. TpsUtil, version 1.44. Stony Brook: Department of Ecology and Evolution, State University of New York at Stony Brook.: http:// life.bio.sunysb.edu/morph/. 01 Jan. 2020.

Sheets HD. 2016a. MakeFan 8. New York, Department of Physics, Canisius, College, Buffalo. http://www.filogenetica.org/cursos/Morfometria/ IMP_installers/index.php. 01 Feb. 2020.

Sheets HD. 2016b. CoordGen 8. New York, Department of Physics, Canisius, College, Buffalo. http://www.filogenetica.org/cursos/Morfometria/ IMP_installers/index.php. 01 Feb. 2020.

Sheets HD. 2016c. PCAGen 8. New York, Department of Physics, Canisius, College, Buffalo. http://www.filogenetica.org/cursos/Morfometria/ IMP_installers/index.php. 01 Feb. 2020.

Sheets HD. 2016d. CVAGen 8. New York, Department of Physics, Canisius, College, Buffalo. http://www.filogenetica.org/cursos/Morfometria/ IMP_installers/index.php. 01 Feb. 2020.

Smith JD. 1893. Undescribed plants from Guatemala. XI. Botanical Gazette 18: 197-211.

Stevens WD. 2009. Apocynaceae. In: Davidse G, Sousa M, Knapp S, Chiang F. (eds.) Flora Mesoamericana. Vol. 4. part. 1. México, DF, London, Universidad Nacional Autónoma de México, Missouri Botanical Garden, The Natural History Museum.p. 733-741.

Templeton AR. 1989. The meaning of species and speciation: a genetic perspective. The units of evolution. Essays on the Nature of Species 1992: 159-183.

Villaseñor JL. 2015. ¿La crisis de la biodiversidad es la crisis de la taxonomía?. Botanical Sciences 93: 03-14.

Viscosi V, Cardini A. 2011. Leaf morphology, taxonomy and geometric morphometrics: a simplified protocol for beginners. PLOS ONE 6: e25630. doi: 10.1371/journal.pone.0025630 